\title{
A szívinfarktusért felelős ér prognosztikus jelentőségének vizsgálata ST-elevációs szívinfarktusos betegekben
}

\author{
Jánosi András dr. ${ }^{1}$. Ofner Péter dr. ${ }^{1}$ \\ Simkovits Dániel dr. ${ }^{1}$. Ferenci Tamás dr. ${ }^{2}$ \\ ${ }^{1}$ Gottsegen György Országos Kardiológiai Intézet, Budapest \\ ${ }^{2}$ Óbudai Egyetem, Neumann János Informatikai Kar, Élettani Szabályozások Csoport, Budapest
}

\begin{abstract}
Bevezetés: A szívinfarktust okozó ér prognosztikai jelentőségére vonatkozóan kevés irodalmi adat áll rendelkezésre, különösen azokban az esetekben, amikor a betegeknél katéteres revascularisatio történt. Célkitúzés: A szerzók célul tüzték ki annak vizsgálatát, hogy a szívinfarktusért felelős érnek (culprit vessel) van-e prognosztikus jelentősége STelevációs myocardialis infarctusos betegekben, akiknél sikeres katéteres érmegnyitás (percutan coronariaintervenció) történt. Módszer: Retrospektív vizsgálatukban 10763 beteg adatait elemezték. A szívinfarktusért felelős ér alapján négy betegcsoportot alakítottak ki: főtörzs, bal leszálló ág, bal körbefutó ág és jobb koszorúér. Az adatok értékelésekor egyváltozós túlélési görbéket konstruáltak, illetve elvégezték a túlélési idő többváltozós modellezését Cox-regresszióval, az életkor, a nem és a társbetegségek figyelembevételével. Eredmények: Leggyakrabban a bal leszálló ág (44,3\%), ezt követte a jobb koszorúér (40,9\%), majd a bal körbefutó ág (13,7\%), míg a fötörzs 1\%-ban volt felelős az infarktus kialakulásáért. Az egyéves túlélés szempontjából a szívinfarktusért felelős ér szignifikáns prognosztikai jelentôséggel bírt ( $\mathrm{p}<0,0001)$ : a jobb koszorúér esetén a hazard ratio 0,69 (95\%-os CI: 0,61-0,79, p<0,0001), a fötörzs esetén 1,56 (95\%-os CI: 1,04-2,35, p =0,0321) volt a referenciaérhez (bal leszálló ág) viszonyítva. Köpetkeztetés: A vizsgálat eredményei igazolják a szívinfarktusért felelős ér prognosztikai jelentőségét. Orv. Hetil., 2016, 157(32), $1282-1288$.
\end{abstract}

Kulcsszavak: ST-elevációs myocardialis infarctus, percutan coronariaintervenció, infarktusért felelős ér, prognózis

\section{Prognostic significance of the culprit vessel in patients with ST-elevation myocardial infarction treated with primary coronary intervention}

\begin{abstract}
Introduction: To the best of the authors' knowledge, very few publications are available which report on the prognostic significance of the culprit vessel in patients with ST elevation myocardial infarction treated with successful primary percutaneous coronary intervention. Aim: The aim of the authors was to obtain data on the significance of the culprit vessel in patients with ST elevation myocardial infarction treated successfully by primary percutaneous coronary intervention. Method: The authors performed a retrospective study in 10,763 patients with ST elevation myocardial infarction who underwent successful primary percutaneous coronary intervention. The culprit vessels were the left main artery, left anterior descendent artery, left circumflex artery, and right coronary artery. The authors constructed univariate survival curves for different culprit vessels and also performed multivariate modelling of timeto-death, controlling for age, sex, and comorbidities. Results: The majority of the culprit lesions were found in the left anterior descendent artery $(44.3 \%)$, the right coronary artery $(40.9 \%)$, and the left circumflex artery $(13.7 \%)$. The culprit vessel was overall a highly significant $(\mathrm{p}<0.0001)$ factor of survival, with right coronary artery exhibiting a highly significantly better prognosis (hazard ratio $0.69,95 \%$ CI $0.61-0.79, \mathrm{p}<0.0001$ ) and left main artery exhibiting a significantly worse prognosis (hazard ratio $1.56,95 \%$ CI $1.04-2.35, \mathrm{p}=0.032 \mathrm{l}$ ) than the reference vessel (left anterior descendent artery). Conclusion: These data demonstrate that the culprit vessel has independent prognostic significance.
\end{abstract}

Keywords: ST elevation myocardial infarction, percutaneous coronary intervention, culprit vessel, prognosis

Jánosi, A., Ofner, P., Simkovits, D., Ferenci, T. [Prognostic significance of the culprit vessel in patients with ST-elevation myocardial infarction treated with primary coronary intervention]. Orv. Hetil., 2016, 157(32), 1282-1288.

(Beérkezett: 2016. április 11.; elfogadva: 2016. május 24.) 


\section{Rövidítések}

$\mathrm{CV}$ = infarktusért felelős ér; LAD = bal leszálló koszorúér; LCx $=$ bal körbefutó coronariaág; IABP = intra-aorticus ballonpumpa; LM = coronaria-fötörzs; NSZR = Nemzeti Szívinfarktus Regiszter; PCI = percutan coronariaintervenció; $\mathrm{RCA}=$ jobb koszorúér; STEMI = ST-elevációs myocardialis infarctus

Számos randomizált, nagy nemzetközi vizsgálat eredménye bizonyította és ma már tankönyvi adat, hogy a heveny szívinfarktus miatt kezelt betegek életkilátásait a revascularisatio különböző formái (thrombolysis, katéteres érmegnyitás) jelentős mértékben javították, és jelenleg ST-elevációs myocardialis infarctus (STEMI) esetén a percutan coronariaintervenció (PCI) az elsődlegesen választandó kezelési mód, ha erre megfelelő időben lehetőség van. A PCI-n kívül számos prognosztikai jelentőségú tényezőt ismerünk, amelyek befolyásolják a betegek életkilátásait, ezek közül a legfontosabbak az életkor, a társbetegségek, az elhalt szívizom nagysága, a koszorúérbetegség kiterjedése. Az általunk ismert irodalomban nem találtunk olyan vizsgálatot, amelyben az infarktusért felelős ér (CV) prognosztikai jelentőségét vizsgálták volna nagyszámú betegen, akiknél sikeres PCI történt. Vizsgálatunkban az infarktusért felelős ér prognosztikai jelentőségét vizsgáltuk olyan betegekben, akiknél az infarktusért felelős ér sikeres katéteres revascularisatiójára került sor.

\section{Módszer}

Az infarktus diagnózisa az érvényes útmutató [1] alapján került felállításra, és STEMI-nek akkor minősítettük az infarktust, ha az ST-eleváció két összetartozó EKG-elvezetésben rögzíthető volt. A Nemzeti Szívinfarktus Regiszter (NSZR) 2010. január 1-jén a Gottsegen György Országos Kardiológiai Intézet kezdeményezésére önkéntes részvétel alapján indult, majd 2014. január 1-jétől törvényi és rendeleti szabályozással országos, kötelezó adatgyüjtésként múködik [2]. Az NSZR egy webalapú adatbázis, amelynek adatait folyamatosan ellenőrizzük, és a szükséges javítások is online történnek. Az indexesemény kapcsán jelenleg 114 adatot rögzítünk: egészségügyi azonosító (taj), név és személyi adatok, társbetegségek, a panasz kezdete, a kórházba érkezés ideje, EKG, biomarker, az ér megnyitásának ideje stb. Az NSZR adatbázisából vizsgálatunkba azokat az infarktusos betegeket válogattuk be, akiknél STEMI miatt került sor a kezelésre, az infarktusért felelős éren sikeres PCI történt, és egyéb éren beavatkozás nem történt. Az infarktusért felelős eret a szívkatéterezést végző orvos jelölte meg, aki a PCI-t követően minősítette a beavatkozást (sikeres vs. sikertelen). A betegek kórlefolyását 1 évig követjük, ennek során rögzítjük az újabb infarktus, szívkatéterezés, stroke, illetve a halál bekövetkezését, az Országos Egészségbiztosítási Pénztár (OEP) adatbázisának adatai alapján. Vizsgálatunk kritériumainak 10763 beteg felelt meg, akiket a CV alapján négy csoportba osztottunk: fötörzs (LM), bal leszálló koszorúér (LAD), bal körbefutó ág (LCx), jobb koszorúér (RCA).

\section{Statisztikai elemzés}

A kategoriális változókat gyakoriság (relatív gyakoriság) formában adtuk meg, és az ilyen változók közötti - CV szerinti csoportok közötti - összehasonlításokat $\chi^{2}$ próbával végeztük. A folytonos változókat átlag (medián) \pm szórás (IQR) (minimum-maximum) formában adtuk meg, és az ilyen változók közötti - CV szerinti csoportok közötti - összehasonlításokat Welch-korrigált egyutas ANOVA-val végeztük. A post hoc tesztelést páronkénti $\chi^{2}$-próbával, illetve Welch-próbával végeztük, a többszörös összehasonlításokra tekintettel Holm-korrekció alkalmazásával.

A halálozásig eltelt idő napi pontossággal volt ismert egészen 1 évvel az indexesemény utánig; a pácienseket, akiket nem tudtunk utánkövetni $(\mathrm{n}=2223)$, illetve akik 1 év után is életben voltak $(n=7103)$ az utolsó információ időpontjában cenzoráltnak vettük. Az egyváltozós túlélési görbéket nemparaméteres Kaplan-Meier-eljárással becsültük.

A halálig eltelt idő modellezését többváltozós Coxregresszióval (Cox proporcionális hazard modell) végeztük [3]. A CV mellett kontrolláltunk az életkorra, nemre, korábbi myocardialis infarctusra és stroke-ra, illetve hypertonia és diabetes mellitus fennállására. (Az olyan prediktorokat, mint a Killip-stádium, IABP-igény, resuscitatio, szándékosan nem használtuk fel, mert úgy találtuk, hogy erősen kollineárisak a CV-vel.)

A proporcionalitást Grambsch és Therneau tesztjével ellenőriztük [4]. Az életkor potenciális nemlineáris hatását úgy vizsgáltuk, hogy a kort korlátozott köbös splinenal transzformálva adtuk a modellhez, majd megvizsgáltuk a nemlinearitás szignifikanciáját [5]. A kapott modell belső validálását 1000 újra-mintavételezéses bootstrappel hajtottuk végre, kiszámítva a túlilleszkedés okozta optimizmusra korrigált mutatókat és a kalibrációs görbét [6]. A többváltozós modell eredményeit hazard arány (HR) alakban adjuk meg, 95\%-os konfidenciaintervallumokkal.

Az elemzést az R statisztikai programcsomag 3.2.1-es változatával hajtottuk végre [7], az rms könyvtár [8] használatával, egy e célra fejlesztett szkript segítségével, amely a levelező szerzőnél elérhető.

\section{Eredmények}

\section{Az infarktusért felelós ér megoszlása}

A CV legnagyobb része a LAD-on volt $(44,3 \%)$, ezt követte a jobb koszorúér (RCA), amely az események 40,9\%-ában, LCx 17,3\%-ában, LM 1\%-ában volt felelős a STEMI-ért. 
1. táblázat |A vizsgált betegcsoportok összehasonlítása

\begin{tabular}{|c|c|c|c|c|c|}
\hline & LAD & LCx & LM & RCA & Különbség \\
\hline$n$ & 4769 & 1481 & 107 & 4406 & \\
\hline Életkor (év) & $\begin{array}{l}\mathrm{n}=4755,63,1(62,9) \\
\pm 13,4(18,9) \\
(19,8-97,5)\end{array}$ & $\begin{array}{l}\mathrm{n}=1480,62,7(61,8) \\
\pm 12(17) \\
(17,9-100,6)\end{array}$ & $\begin{array}{l}\mathrm{n}=107,66,3(65,8) \\
\pm 12.8(21) \\
(37-93,7)\end{array}$ & $\begin{array}{l}\mathrm{n}=4400,63,3 \\
(62,6) \pm 12.1(17,1) \\
(18,6-97,4)\end{array}$ & $\begin{array}{l}p=0,02761 \\
\text { LM vs. } L A D: p=0,061 \\
\text { LM vs. } L C x: p=0,033 \\
\text { LM vs. } R C A: p=0,071\end{array}$ \\
\hline Férfi & $\begin{array}{l}\mathrm{n}=4769 \\
2958(62 \%)\end{array}$ & $\begin{array}{l}\mathrm{n}=1481 \\
984(66,4 \%)\end{array}$ & $\begin{array}{l}\mathrm{n}=107 \\
72(67,3 \%)\end{array}$ & $\begin{array}{l}\mathrm{n}=4406 \\
2715(61,6 \%)\end{array}$ & $\begin{array}{l}p=0,005143 \\
\text { LCx vs. LAD: } p=0,012 \\
\text { RCA vs. } L C x: p=0,006\end{array}$ \\
\hline Aktív dohányos & $\begin{array}{l}\mathrm{n}=3484, \\
1565(44,9 \%)\end{array}$ & $\begin{array}{l}\mathrm{n}=1083 \\
511(47,2 \%)\end{array}$ & $\begin{array}{l}\mathrm{n}=67 \\
30(44,8 \%)\end{array}$ & $\begin{array}{l}\mathrm{n}=3198 \\
1634(51,1 \%)\end{array}$ & $\begin{array}{l}\mathrm{p}<0,0001 \\
\text { LAD vs. RCA: } \mathrm{p}<0,0001\end{array}$ \\
\hline Magas vérnyomás & $\begin{array}{l}\mathrm{n}=4426 \\
3143(71 \%)\end{array}$ & $\begin{array}{l}\mathrm{n}=1367 \\
999(73,1 \%)\end{array}$ & $\begin{array}{l}\mathrm{n}=99 \\
73(73,7 \%)\end{array}$ & $\begin{array}{l}\mathrm{n}=4046 \\
2940(72,7 \%)\end{array}$ & $\mathrm{p}=0,2651$ \\
\hline Cukorbetegség & $\begin{array}{l}\mathrm{n}=4263 \\
1085(25,5 \%)\end{array}$ & $\begin{array}{l}\mathrm{n}=1332 \\
341(25,6 \%)\end{array}$ & $\begin{array}{l}\mathrm{n}=95 \\
29(30,5 \%)\end{array}$ & $\begin{array}{l}\mathrm{n}=3929 \\
1031(26,2 \%)\end{array}$ & $p=0,6164$ \\
\hline $\begin{array}{l}\text { Perifériás } \\
\text { érbetegség }\end{array}$ & $\begin{array}{l}\mathrm{n}=4076 \\
351(8,6 \%)\end{array}$ & $\begin{array}{l}\mathrm{n}=1260 \\
127(10,1 \%)\end{array}$ & $\begin{array}{l}\mathrm{n}=91 \\
18(19,8 \%)\end{array}$ & $\begin{array}{l}\mathrm{n}=3734 \\
400(10,7 \%)\end{array}$ & $\begin{array}{l}p=0,0001384 \\
\text { LM vs. } L A D: p=0,0026 \\
\text { LM vs. } L C x: p=0,0268 \\
\text { RCA vs. } L A D: p=0,0094 \\
\text { RCA vs. } L M: p=0,0306\end{array}$ \\
\hline $\begin{array}{l}\text { Kórelőzményben } \\
\text { szívinfarktus }\end{array}$ & $\begin{array}{l}\mathrm{n}=4251 \\
604(14,2 \%)\end{array}$ & $\begin{array}{l}\mathrm{n}=1305 \\
241(18,5 \%)\end{array}$ & $\begin{array}{l}\mathrm{n}=97 \\
24(24,7 \%)\end{array}$ & $\begin{array}{l}\mathrm{n}=3905 \\
576(14,8 \%)\end{array}$ & $\begin{array}{l}p<0,0001 \\
\text { LCx vs. } L A D: p=0,0013 \\
\text { LM vs. } L A D: p=0,0223 \\
\text { RCA vs. } L C x: p=0,0081 \\
\text { RCA vs. } L M: p=0,0297\end{array}$ \\
\hline Megelőző stroke & $\begin{array}{l}\mathrm{n}=4218 \\
325(7,7 \%)\end{array}$ & $\begin{array}{l}\mathrm{n}=1302 \\
106(8,1 \%)\end{array}$ & $\begin{array}{l}\mathrm{n}=96 \\
10(10,4 \%)\end{array}$ & $\begin{array}{l}\mathrm{n}=3885 \\
343(8,8 \%)\end{array}$ & $\mathrm{p}=0,2626$ \\
\hline
\end{tabular}

A kategoriális változókat gyakoriság (relatív gyakoriság) formában adtuk meg, és az ilyen változók közötti - CV szerinti csoportok közötti - öszszehasonlításokat $\chi^{2}$-teszttel végeztük. A folytonos változókat átlag (medián) \pm szórás (IQR) (minimum-maximum) formában adtuk meg, és az ilyen változók közötti - CV szerinti csoportok közötti - összehasonlításokat Welch-korrigált egyutas ANOVA-val végeztük. A post hoc tesztelést páronkénti $\chi^{2}$-próbával, illetve Welch-próbával végeztük, a többszörös összehasonlításokra tekintettel Holm-korrekció alkalmazásával. A post hoc teszteknél a 0,1 alatti p-értékü összehasonlításokat tüntettük fel.

\section{A vizsgált betegcsoportok jellemzô" adatai}

A betegcsoportok fontosabb adatait az 1. táblázatban foglaltuk össze. Az LM-csoportba tartozó betegek idősebbek voltak, gyakrabban volt perifériás érbetegségük és gyakoribb volt kórelőzményükben a megelőző szívinfarktus. Az LCx-csoportban nagyobb volt a férfiak aránya, míg az RCA-csoportban több beteg dohányzott. Nem találtunk különbséget a vizsgált csoportok között a magas vérnyomás, a diabetes mellitus és a megelőző stroke előfordulásában.

\section{Kórbázi szöpôdmények}

A kórházi szövődmények előfordulását a 2. táblázat tartalmazza. Az LM-csoportban jelentősen gyakoribb volt a komplikációk előfordulása $(\mathrm{p}<0,0001)$ az összes többi csoporthoz viszonyítva: gyakoribb volt a sokk, az intraaorticus ballonpumpa, a mechanikus lélegeztetés alkalmazása, illetve resuscitatióra is többször került sor. A LAD-csoportban a felsorolt komplikációk gyakoribbak voltak, mint az LCx-, illetve RCA-csoportban.

\section{Balkamra-funkció}

A kórházi kibocsátás előtt szívultrahang 4618 betegnél $(42,9 \%)$ történt. Az LM-csoportban, illetve kisebb mértékben a LAD-csoportban a csökkent (EF: 30-39\%), illetve a súlyosan csökkent $(\mathrm{EF}<29 \%)$ ejectiós frakciójú betegek többen voltak, mint a másik két betegcsoportban (1. ábra).

\section{A kórházi kezelés során alkalmazott és az elbocsátáskor javasolt gyógyszeres kezelés}

A szekunder prevenció szempontjából is szükséges gyógyszeres kezelés arányát a 3. táblázat tartalmazza. A betegek túlnyomó többsége részesült az irányelvek által javasolt kezelésben.

\section{A betegek életkilátásainak vizsgálata}

A CV alapján kialakított betegcsoportok túlélési görbéit a 2. ábra mutatja. A többváltozós modellben az életkor- 


\begin{tabular}{|c|c|c|c|c|c|}
\hline & LAD & LCx & LM & RCA & Különbség \\
\hline$n$ & 4769 & 1481 & 107 & 4406 & \\
\hline Kardiogén sokk & $\mathrm{n}=4574,305(6,7 \%)$ & $\mathrm{n}=1403,80(5,7 \%)$ & $\mathrm{n}=105,31(29,5 \%)$ & $\mathrm{n}=4206,234(5,6 \%)$ & $\begin{array}{l}\mathrm{p}<0,0001 \\
\text { LM vs. } \mathrm{LAD}: \mathrm{p}<0,0001 \\
\text { LM vs. } \mathrm{LC}: \mathrm{p}<0,0001 \\
\text { RCA vs. } \mathrm{LM}: \mathrm{p}<0,0001\end{array}$ \\
\hline Gépi lélegeztetés & $\mathrm{n}=4577,402(8,8 \%)$ & $\mathrm{n}=1404,109(7,8 \%)$ & $\mathrm{n}=105,29(27,6 \%)$ & $\mathrm{n}=4201,261(6,2 \%)$ & $\begin{array}{l}\mathrm{p}<0,0001 \\
\text { LM vs. } \mathrm{LAD}: \mathrm{p}<0,0001 \\
\text { LM vs. } \mathrm{LCx}: \mathrm{p}<0,0001 \\
\text { RCA vs. } \mathrm{LAD}: \mathrm{p}<0,0001 \\
\text { RCA vs. } \mathrm{LM}: \mathrm{p}<0,0001\end{array}$ \\
\hline $\begin{array}{l}\text { Intraaorticus } \\
\text { ballonpumpa }\end{array}$ & $\mathrm{n}=4576,224(4,9 \%)$ & $\mathrm{n}=1401,46(3,3 \%)$ & $\mathrm{n}=105,26(24,8 \%)$ & $\mathrm{n}=4200,112(2,7 \%)$ & $\begin{array}{l}\mathrm{p}<0,0001 \\
\text { LCx vs. } \mathrm{LAD}: \mathrm{p}=0,027 \\
\text { LM vs. } \mathrm{LAD}: \mathrm{p}<0,0001 \\
\text { LM vs. } \mathrm{LCx}: \mathrm{p}<0,0001 \\
\text { RCA vs. } \mathrm{LAD}: \mathrm{p}<0,0001 \\
\text { RCA vs. } \mathrm{LM}: \mathrm{p}<0,0001\end{array}$ \\
\hline Resuscitatio & $\mathrm{n}=4560,336(7,4 \%)$ & $\mathrm{n}=1399,83(5,9 \%)$ & $\mathrm{n}=104,20(19,2 \%)$ & $\mathrm{n}=4190,235(5,6 \%)$ & $\begin{array}{l}\mathrm{p}<0,0001 \\
\text { LCx vs. } \mathrm{LAD}: \mathrm{p}=0,027 \\
\text { LM vs. } \mathrm{LAD}: \mathrm{p}<0,0001 \\
\text { LM vs. } \mathrm{LCx}: \mathrm{p}<0,0001 \\
\text { RCA vs. } \mathrm{LAD}: \mathrm{p}<0,0001 \\
\text { RCA vs. } \mathrm{LM}: \mathrm{p}<0,0001\end{array}$ \\
\hline
\end{tabular}

A kategoriális változókat gyakoriság (relatív gyakoriság) formában adtuk meg, és az ilyen változók közötti - CV szerinti csoportok közötti - öszszehasonlításokat $\chi^{2}$-teszttel végeztük. A folytonos változókat átlag (medián) \pm szórás (IQR) (minimum-maximum) formában adtuk meg, és az ilyen változók közötti - CV szerinti csoportok közötti - összehasonlításokat Welch-korrigált egyutas ANOVA-val végeztük. A post hoc tesztelést páronkénti $\chi^{2}$-próbával, illetve Welch-próbával végeztük, a többszörös összehasonlításokra tekintettel Holm-korrekció alkalmazásával. A post hoc teszteknél a 0,1 alatti $p$ értékú összehasonlításokat tüntettük fel.

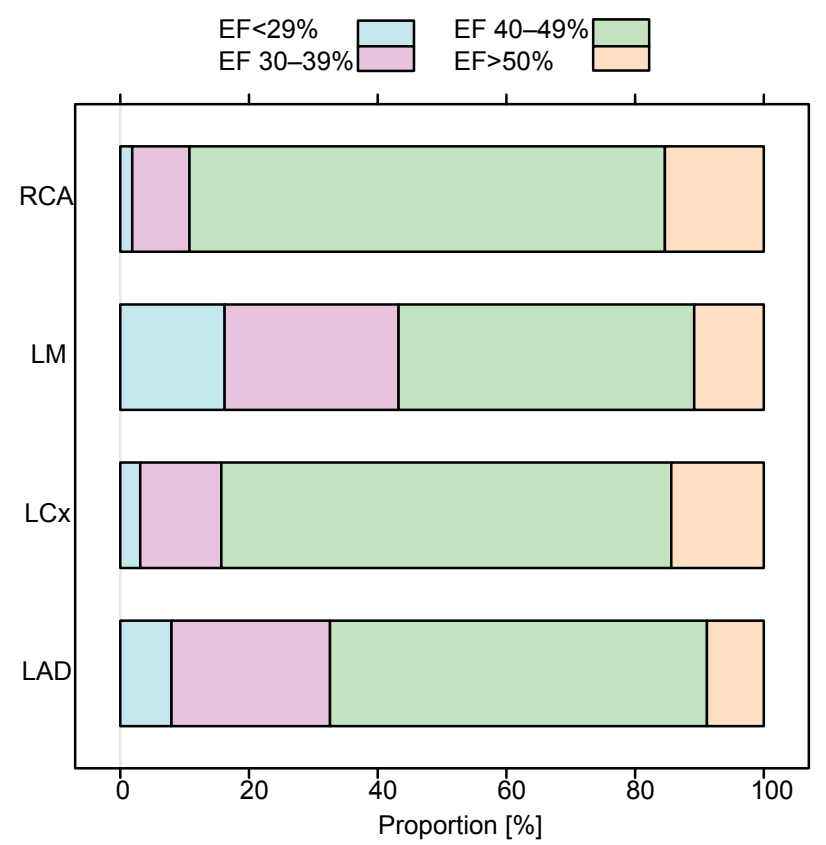

1. ábra

A különböző bal kamrai ejectiós frakciók előfordulási gyakorisá ga a culprit ér szerinti csoportokban

beli nemlinearitás szükségtelennek bizonyul $(\mathrm{p}=$ 0,1639). A modell proporcionalitására vonatkozó teszt minden szokásos szignifikanciaszinten szignifikáns lett, ám ezt jórészt a korábbi infarktus okozta, így a modellt e

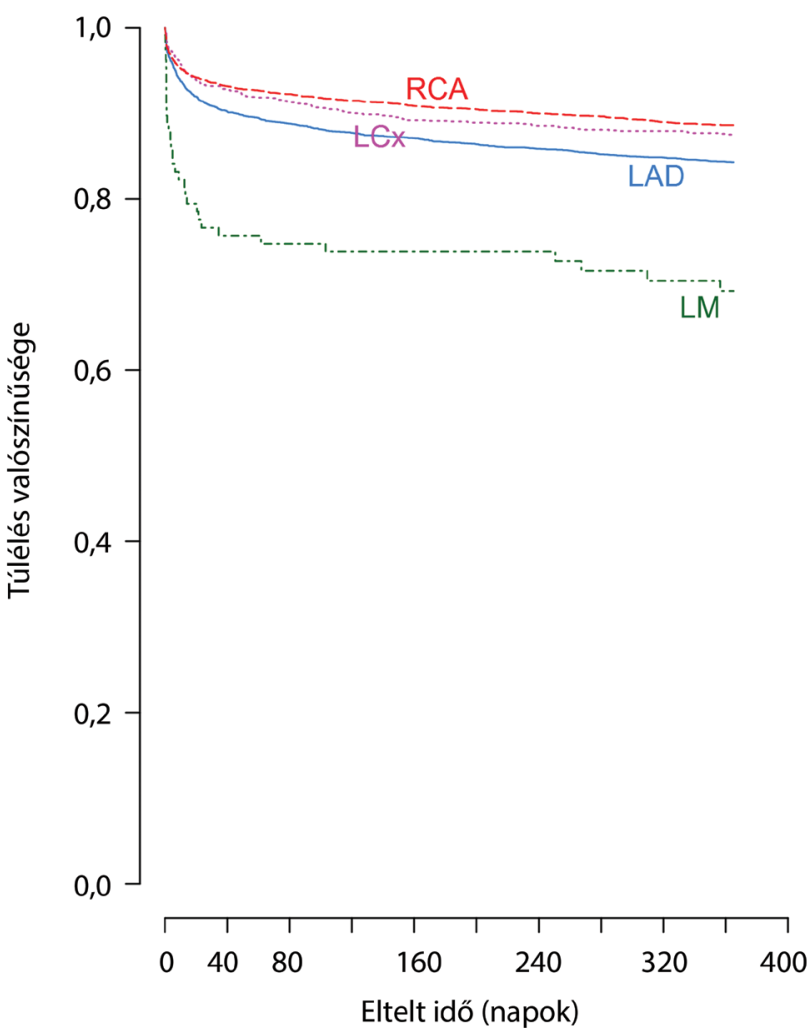

2. ábra |A túlélési görbék a culprit ér szerinti csoportokban 
3. táblázat |A kórházi elbocsátáskor alkalmazott gyógyszeres kezelés

\begin{tabular}{lllll}
\hline & LAD & LCx & LM & RCA \\
\hline$n$ & 4769 & 1481 & 107 & 4406 \\
\hline ACEI/ARB & $\mathrm{n}=4693,4104(87,4 \%)$ & $\mathrm{n}=1457,1268(87 \%)$ & $\mathrm{n}=103,77(74,8 \%)$ & $\mathrm{n}=4353,3764(86,5 \%)$ \\
BB & $\mathrm{n}=4701,4153(88,3 \%)$ & $\mathrm{n}=1458,1268(87 \%)$ & $\mathrm{n}=103,75(72,8 \%)$ & $\mathrm{n}=4354,3696(84,9 \%)$ \\
Aszpirin & $\mathrm{n}=4648,4077(87,7 \%)$ & $\mathrm{n}=1438,1256(87,3 \%)$ & $\mathrm{n}=102,82(80,4 \%)$ & $\mathrm{n}=4308,3791(88 \%)$ \\
Clopidogrel & $\mathrm{n}=4309,4126(95,8 \%)$ & $\mathrm{n}=1337,1284(96 \%)$ & $\mathrm{n}=83,75(90,4 \%)$ & $\mathrm{n}=4016,3868(96,3 \%)$ \\
Statin & $\mathrm{n}=4403,4272(97 \%)$ & $\mathrm{n}=1371,1320(96,3 \%)$ & $\mathrm{n}=93,82(88,2 \%)$ & $\mathrm{n}=4107,3972(96,7 \%)$ \\
\hline
\end{tabular}

ACEI = angiotenzinkonvertálóenzim-gátló; $\mathrm{ARB}=$ angiotenzinreceptor-blokkoló, $\mathrm{BB}$ = béta-receptor-blokkoló.

szerint rétegeztük. (Megakadályozva e tényező elemzését, viszont lényegében kijavítva ilyen szempontból a modellt: a rétegzett modellre e teszt eredménye már $\mathrm{p}=$ 0,03497 volt.) A modellt - 95\%-os konfidenciaintervallumokkal ellátott HR-ekkel - a 3. ábra mutatja.

A CV összességében nagyon jelentős prognosztikai tényezőnek bizonyult ( $\mathrm{p}<0,0001)$ : az RCA-csoportnak szignifikánsan jobb túlélését figyeltük meg $(\mathrm{HR}=0,69$, 95\%-os CI: 0,61-0,79, p<0,0001), míg az LM-csoportban a prognózis szignifikánsan rosszabb volt $(\mathrm{HR}=$ 1,56, 95\%-os CI: 1,04-2,35, p = 0,0321), mint a referenciacsoportnak tekintett LAD-betegeknél. Az LCxcsoport rosszabb prognózisa nem bizonyult szignifikánsnak $(\mathrm{HR}=0,84,95 \%$-os CI: 0,70-1,01, $\mathrm{p}=0,0617)$. A CV-n kívül a betegek életkora bizonyult igen jelentősnek a túlélés szempontjából $(\mathrm{HR}=1,070$ minden év növekedésre, 95\%-os CI: 1,063-1,075, p<0,0001). A kórelőzményben szereplő betegségek (magas vérnyomás, cukorbetegség, megelőző stroke) a túlélés szempontjából szignifikáns prognosztikai tényezők voltak. Szemben a cukorbetegséggel és a megelőző agyi történéssel, a hypertonia érdekes módon nem fokozta, hanem csökkentette a halálozás kockázatát. A beteg neme nem befolyásolta a prognózist ( $\mathrm{p}=0,3785)$.

A modell korrigált $\mathrm{R}^{2}$-e 0,1010 volt, ami gyenge illeszkedést jelent, de a modell kalibrációja kitűnő volt.

\section{Megbeszélés}

$\mathrm{Az}$ általunk ismert irodalomban nem találtunk olyan közleményt, amelyben a CV prognosztikus jelentőségét vizsgálták nagy betegszámú, PCI-vel kezelt STEMI-populáción. Betegeinket a Nemzeti Szívinfarktus Regiszter adatbázisából választottuk ki, amelynek adatai jellegénél fogva reprezentálják a mindennapi gyakorlatot („real world data”). A CV gyakoriságát vizsgálva azt találtuk, hogy a LAD volt a leggyakoribb CV, amit RCA és LCx követett. Ezzel megegyező gyakoriságot közöltek több közleményben [9-12]. Adataink a CV prognosztikus jelentőségét igazolták: az LM-betegcsoportban találtuk a legrosszabb prognózist, ezt a LAD-csoportba tartozó betegek követték. A kórházi szövődmények aránya és a halálozás kockázata ezekben a betegcsoportokban szignifikánsan magasabb volt. A kórházi elbocsátás előtt a betegek közel felénél készült echokardiográfia. A súlyosan csökkent ejectiós frakció $(\mathrm{EF}<35 \%)$ ugyancsak az LM- és a LAD-betegcsoportokban volt szignifikánsan gyakoribb az RCA- és LCx-csoportokhoz hasonlítva. Baek és mtsai [13] a Koreai Infarktus Regiszter anyagában összehasonlították az LM és az egyéb éren végzett PCI eredményességét és azt találták, hogy az LM-betegcsoportban az utánkövetés 12 hónapja alatt magasabb volt a súlyos kardiális események előfordulása (cardiovascularis halálozás, nem halálos reinfarktus és az ismételt revascularisatio). A különbség döntően az 1 hónap alatt bekövetkező halálesetekből adódott. Számos egyéb tanulmány hasonló adatokat közölt [14-16]. Chen és mtsai

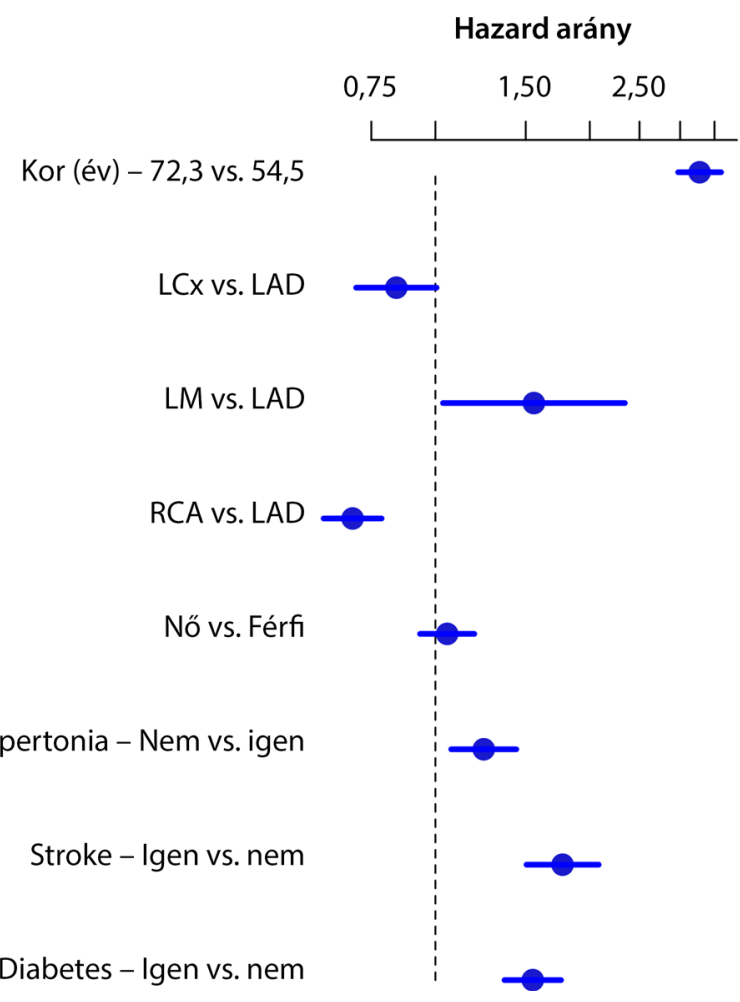

3. ábra $\mid$ A túlélési időre adott többváltozós Cox regressziós modell eredményei. A pontok a hazard arányra adott pontbecsléseket jelzik, a csíkok a rájuk vonatkozó 95\%-os konfidenciaintervallumot mutatják. A kategóriális változóknál a leggyakoribb kategóriához viszonyítottunk, a folytonos változónál pedig az 1 interkvartilis terjedelemnyi növekedéshez tartozó értéket tüntettük fel 
[17] inferior lokalizációjú infarktus esetén összehasonlította az RCA- versus LCx-occlusio prognózisát olyan betegeknél, akiknél PCI történt. Adataik szerint az RCA-occlusio kezelését követően a betegeknek jobb volt a prognózisuk, mint azoknál, akiknek az infarktusát az LCx-elzáródás okozta. Mikkelsson és mtsai vizsgálatukban [18] azt találták, hogy a jobb koszorúér-elzáródás gyakoribb volt azokban a betegekben, akik a praehospitalis időszakban meghaltak, szemben azokkal, akik a kórházba jutottak.

Vizsgálatunk korlátai a következők: Az infarktusos betegek prognózisát döntően az elhalt szívizom tömege határozza meg, amit az ischaemiás idő, a veszélyeztetett szívizom tömege és a reperfúziós károsodás befolyásol [19]. Vizsgálatunkban az ischaemiás időre, illetve a reperfúziós károsodásra vonatkozó adatokkal nem rendelkeztünk. A CV prognosztikai jelentőségének igazolása arra utal, hogy a CV közvetett jelzője a veszélyeztetett szívizom tömegének, ezért bizonyul fontos prognosztikai tényezőnek. A betegek közel felénél rendelkeztünk csak echokardiográfiás adatokkal, így a szívizom-károsodás mértékére - az egész populáció tekintetében - nem vonhatók le következtetések. További hiányossága tanulmányunknak az, hogy nem rendelkeztünk olyan adatokkal, amelyek az érelzáródás lokalizációjára (proximalis versus distalis), illetve a coronariakeringés dominanciájára vonatkoztak. Irodalmi adatok szerint mindezek befolyásolják a prognózist [20-24].

\section{Következtetés}

Vizsgálatunk adatai szerint az infarktusért felelős érnek önálló prognosztikai jelentősége van. A CV valószínúleg közvetetten jelzi a veszélyeztetett myocardium tömegét.

Anyagi támogatás: A közlemény megírása, illetve az ahhoz kapcsolódó kutatómunka anyagi támogatásban nem részesült.

Szerzői munkamegosztás: J. A.: A kutatás megtervezése, az eredmények értékelése, a kézirat megírása. O. P.: Az eredmények értékelése, a kézirat végleges formájának kialakítása. S. D.: Anyaggyújtés, eredmények elemzése, irodalomkutatás. F. T.: A statisztikai elemzés elvégzése és az eredmények értékelése, a kézirat megírása. A cikk végleges változatát valamennyi szerző elolvasta és jóváhagyta.

Érdekeltségek: A szerzőknek nincsenek érdekeltségeik.

\section{Köszönetnyilvánitás}

A szerzők köszönettel tartoznak a Nemzeti Szívinfarktus Regiszter munkájában részt vevő kollégáknak. A jelen közleménnyel kapcsolatban a szívkatéteres centrumok vezetóinek: Dr. Andrássy Péter, Prof. Dr. Andréka Péter, Prof. Dr. Dézsi Csaba András, Prof. Dr. Édes István, Prof. Dr. Forster Tamás, Dr. Horváth Iván, Dr. Herczeg Béla,
Dr. Katona András, Dr. Kerkovits Gábor, Prof. Dr. Kiss Róbert Gábor, Dr. Lupkovics Géza, Prof. Dr. Merkely Béla, Dr. Nagy Gergely György, Prof. Dr. Nagy Lajos, Prof. Dr. Polgár Péter, Dr. Ruzsa Zoltán, Prof. Dr. Tomcsányi János, Prof. Dr. Veress Gábor külön is köszönik együttmúködésüket. A szerzők továbbá köszönik Póth Anikó és Zorándi Ágnes lelkiismeretes munkáját.

\section{Irodalom}

[1] Thygesen, K., Alpert, J. S., Jaffe, A. S., et al., Writing Group on Behalf of the Joint ESC/ACCF/AHA/WHF Task Force for the Universal Definition of Myocardial Infarction: Third universal definition of myocardial infarction. Eur. Heart J., 2012, 33(20), 2551-2567.

[2] Jánosi, A., Ofner, P., Forster, T., et al.: Clinical characteristics, hospital care, and prognosis of patients with ST elevation myocardial infarction. Hungarian Myocardial Infarction Registry. Eur. Heart J., 2014, 16(Suppl. A), Al2-A15.

[3] Hosmer, D. W. Lemeshow, S., May, S.: Applied survival analysis. Regression modelling of time to event data. John Wiley \& Sons, New York, 2011.

[4] Grambsch, P. M., Thernean, T. M.: Proportional hazards tests and diagnostics based on weighted residuals. Biometrika, 1994, $81(3), 515-526$.

[5] Harrell, F. E.: Regression modelling strategies. Springer, Science and Business Media, New York, 2001.

[6] Steyerberg, E. W.: Clinical prediction models: A practical approach to development, validation and updating. Springer, Science and Business Media, New York, 2009.

[7] $R$ Development Core Team: R: a language and environment for statistical computing. R Foundation for Statistical Computing, Vienna, 2015. http://www.gbif.org/resource/81287

[8] Harrell, F. E.: RMS: Regression Modelling Strategies. R package version 4.3-2. 2015. http://biostat.mc.vanderbilt.edu/rms

[9] Stone, G. W., Lansky, A. J., Pocock, S. J., et al.: Paclitaxel-eluting stents versus bare-metal stents in acute myocardial infarction. N. Engl. J. Med., 2009, 360(19), 1946-1959.

[10] Prati, F., Petronio, S., Van Boven, A. J., et al.: Evaluation of infarct-related coronary artery patency and microcirculatory function after facilitated percutaneous primary coronary angioplasty: the FINESSE-ANGIO (Facilitated Intervention With Enhanced Reperfusion Speed to Stop Events-Angiographic) study. J. Am. Coll. Cardiol. Cardiovasc. Interv., 2010, 3(12), 1284-1291.

[11] Stone, S. G., Serrao, G. W., Mehran, R., et al.: Incidence, predictors, and implications of reinfarction after primary percutaneous coronary intervention in ST-segment-elevation myocardial infarction: the Harmonizing Outcomes with Revascularization and Stents in Acute Myocardial Infarction Trial. Circ. Cardiovasc. Interv., 2014, 7(4), 543-551.

[12] Antoni, M. L., Yiu, K. H., Atary, J. Z., et al.: Distribution of culprit lesions in patients with ST-segment elevation acute myocardial infarction treated with primary percutaneous coronary intervention. Coron. Artery Dis., 2011, 22(8), 533-536.

[13] Baek, J. Y., Seo, S. M., Park, H. J., et al.: Clinical outcomes and predictors of unprotected left main stem culprit lesions in patients with acute ST segment elevation myocardial infarction. Catheter Cardiovasc. Interv., 2014, 83(7), E243-E250.

[14] Izumikawa, T., Sakamoto, S., Takeshita, S., et al.: Outcomes of primary percutaneous coronary intervention for acute myocardial infarction with unprotected left main coronary artery occlusion. Catheter Cardiovasc. Interv., 2012, 79(7), 1111-1116.

[15] Lee, M. S., Sillano, D., Latib, A., et al.: Multicenter international registry of unprotected left main coronary artery percutaneous coronary intervention with drug-eluting stents in patients with myocardial infarction. Catheter Cardiovasc. Interv., 2009, 73(1), $15-21$.

[16] Puricel, S., Adorjan, P., Oberbänsli, M., et al.: Clinical outcomes after PCI for acute coronary syndrome in unprotected left main 
coronary artery disease: insights from the Swiss Acute Left Main Coronary Vessel Percutaneous Management (SALVage) study. EuroIntervention, 2011, 7(6), 697-704.

[17] Chen, Y. L., Hang, C. L., Fang, H. Y., et al.: Comparison of prognostic outcome between left circumflex artery-related and right coronary artery-related acute inferior wall myocardial infarction undergoing primary percutaneous coronary intervention. Clin. Cardiol., 2011, 34(4), 249-253.

[18] Mikkelsson, J., Eskola, M., Nikus, K., et al.: Fatality of myocardial infarction in relation to the coronary anatomy: the role of culprit lesion location. Ann. Med., 2004, 36(6), 474-479.

[19] Sörensson, P., Heiberg, E., Saleh, N., et al.: Assessment of myocardium at risk with contrast enhanced steady-state free precession cine cardiovascular magnetic resonance compared to single-photon emission computed tomography. J. Cardiovasc. Magn. Reson., 2010, 12, 25.

[20] Harjai, K. J., Mehta, R. H., Stone, G. W., et al.: Does proximal location of culprit lesion confer worse prognosis in patients undergoing primary percutaneous coronary intervention for ST elevation myocardial infarction? J. Interv. Cardiol., 2006, 19(4), 285-294.
[21] Elsman, P., van't Hof, A. W., Hoorntje, J. C., et al.: Effect of coronary occlusion site on angiographic and clinical outcome in acute myocardial infarction patients treated with early coronary intervention. Am. J. Cardiol., 2006, 97(8), 1137-1141.

[22] Seo, S. M., Kim, T. H., Kim, C. J., et al.: Prognostic impact of significant non-infarct-related left main coronary artery disease in patients with acute myocardial infarction who receive a culpritlesion percutaneous coronary intervention. Coron. Artery Dis., 2012, 23(5), 307-314

[23] Abu-Assi, E., Castiñeira-Busto, M., González-Salvado, V., et al.: Coronary artery dominance and long term prognosis in patients with ST-segment elevation myocardial infarction treated with primary angiolasty. Rev. Esp. Cardiol. (Engl. ed.), 2016, 69(1), 19-27.

[24] Su, M. I., Tsai, C. T., Yeh, H. I., et al.: The impact of SYNTAX score of non-infarct-related artery on long-term outcome among patients with acute ST segment elevation myocardial infarction undergoing primary percutaneous coronary intervention. PLoS ONE, 2014, $9(10)$, el09828.

(Jánosi András dr., Budapest, Haller u. 29., 1096 e-mail: janosi.andras@kardio.hu)

\section{FELHÍVÁS \\ folyóirat-referátumok beküldésére}

A Semmelweis Egyetem Továbbképző Központjának döntése értelmében 2016. január 1-jétöl folyamatosan orvos-továbbképzési pontokat kaphatnak a nemzetközi, impaktfaktoros folyóiratokban megjelent közlemények rövid összefoglalásának, referátumának beküldői.

Az Orvosi Hetilap hasábjain megjelenő és közlésre elfogadott referátum után 1 pont, félévente maximum 12 továbbképzési pont gyüjthető, amelyet félévente összesítve továbbitunk a továbbképzési központok felé.

Távoktatással szerzett pontokból évente legfeljebb 20 pont számítható be.

Aki továbbképzési pontot kiván gyüjteni, a referátum beküldésekor adja meg pecsétszámát.

Várjuk lelkes, továbbképzési pontokat gyüjteni kivánó referálóink jelentkezését!

\section{A referátum fejlécében az alábbi adatokat kérjük megadni:}

A cikk címe magyarul, zárójelben az angol cím

A szerző(k) neve (vezetéknév, a keresztnevet jelölő betü(k) - 3 szerzőig, háromnál több szerző esetén et al.), a levelező szerző neve, munkahelye és e-mail címe)

A folyóirat neve - a szokásos nemzetközi rövidítés szerint (PubMed), évszám, kötetszám, füzetszám, a cikk kezdő és utolsó oldalszáma

A referátumot elektronikus úton (Editorial Manager vagy e-mail: edit.budai@akademiai.hu) kérjük elküldeni. 